\title{
New Preparations for Winter Wheat Seeds Protection
}

\author{
V.A. GULIDOVA, R.V. SHCHUCHKA \\ FSBEI HE Yelets State University named after I.A. Bunin, Yelets, RUSSIA
}

\begin{abstract}
The research results into the different seed dressing agents effect on winter wheat seeds sowing qualities are presented. In the experiment, effective combination preparations with multilateral insectofungicidal activity were studied. The presence of several active substances in the preparation reduces the pesticide burden on the environment. Under field conditions close to production conditions the Sistiva, Kuinto Duo, Imidashans, Chansometox, Shansil Ultra, Shansil Trio, Vaibrans Integral, Celest Max, Celest Top effect at recommended doses were studied. At present, for winter wheat seed dressing it is best to use insectofungicide preparations containing different chemical classes several components. The best indicators for productivity $(7.23 \mathrm{t} / \mathrm{ha})$ and grain quality among the studied preparations were obtained by using a fourcomponent insectofungicide for winter wheat seed disinfestation Vaibrans Integral, KS at the rate of 21/t. Its use provides not only high yield but also particularly high protein content in the grain $(16.07 \%)$ and gluten $(36.8 \%)$ of the first quality group. If we take the winter wheat yield as a basis, in this indicator terms the worst performance was that of Celest Top. Nevertheless, all the studied preparations can be used to disinfect winter wheat seeds from seed and soil infections, as well as from harmful insects of the early period of plant development.
\end{abstract}

Keywords - seed born infection, seed dressing, winter wheat, yield, gluten, protein, insectofungicides, germination, fungicides, insecticides.

Received: February 15, 2021. Revised: June 7, 2021. Accepted: June 16, 2021. Published: June 23, 2021.

\section{Introduction}

A $\mathrm{T}$ the agriculture development present stage in Russia, much attention to crop production is paid to food grain production. Winter wheat has the largest share in the increase in gross grain harvest. Stable grain production is the each agricultural enterprise's budget revenues formation an integral part from its sales. The grain industry state directly determines the people provision with food and the livestock industry with nutritious fodder. The grain market in Russia is the food market a large segment, through which more than $40 \%$ of the agricultural production volume is sold. A food grain producer tries to increase the grain field productivity. Intensification one element is the cultivation technology improvement, including agricultural techniques modern, innovative elements. Seed dressing with modern preparations is one of these agricultural practices. At present, the implementation of this element of technology is of particular importance due to the widespread use of soil treatment without turnover, zero treatment of No-till and Strip Tillage treatment. Fine surface treatment of soil leads to deterioration of phytosanitary situation of topsoil, where a significant number of phytopathogens and phytophages accumulate and survive on plant residues, which prevent plants from passing the most vulnerable period from seed germination to formation of full seedlings [14]. To help the plant during this period (BBCH 01-10) is intended to be such an agricultural technique as decontamination of seed material with chemicals.

Seed dressing is crop protection products an effective, costeffective, most environmentally friendly and technologically advanced application [6,7]. This plant protection method advantage is low cost per unit area, application ease, especially on an industrial basis, and action efficiency. According to the All-Russian Research Institute of Plant Chemicals data, dressing limits the seed infection manifestation by $60-100 \%$ and primary aerogenic infection by $30-80 \%$ contained in soil and crop residues, which provides an increase in winter wheat yield from 0.3 to $0.6 \mathrm{t} / \mathrm{ha}$ [1]. In the forming process, the pesticides range for pre-sowing seed treatment special attention is paid to the drugs' selection that may have fungicidal, insecticidal or insectofungicidal properties. Many preparations have a stimulating effect on the plants' growth and development, help to increase winter hardiness and improve the plants overwintering [15]. Thanks to them, the spraying period during the growing season is postponed, their number is reduced when protecting against leaf spots (Septoria tritici, S. nodorum, Pyrenophora tritici-repentis), Blumeria graminis and Puccinia recondita. Therefore, dressing is the 
basis for healthy, friendly germination, plants uniform distribution over the area and high yields.

Seed treatment should be preceded by a phytopathological examination of the seed material, which determines the species composition of the pathogen and the degree of infection of the seeds $[6,13,4,10]$. At present more than 120 fungicides and about 27 insecticides for seed treatment have been registered in the Russian Federation. These formulations are based on 32 active substances belonging to different chemical classes. Moreover, new preparations are usually multi-component with multilateral insectofungicidal activity. Each year the products' range is updated and new ones are added. It is an effective tool for seed protection management when applied correctly and scientifically. Therefore, this study purpose was to identify the most effective new generation seed protectors for winter wheat, suitable for use in the Central Chernozem region typical forest-steppe conditions and provide high crop productivity and the resulting products high quality.

\section{Research Methodology}

To solve this task the research was conducted on the Tula region KFKh Krapp fields. The research objects were preparations intended for cereal crops seed dressing: Sistiva, Kinto Duo, Imidashans, Shansometox, Shansil Ultra, Shansil Trio, Vybrance Integral, Celest Max, Celest Top and winter wheat variety Nemchinovskaya plants 17 (Table 1). All studied preparations have the same preparative form suspension concentrate (CS). As a control variant, a threecomponent fungicide (Shansil Trio) and an insecticide (Imidashans) a tank mixture was used. This variant is widely used in farms growing winter wheat. The research other objects choice was justified by the fact that the preparations meet modern requirements, are actively offered by producers and are in high demand among commodity producers. All studied preparations are included in the catalogue [5]. The experimental plot soil was heavy loamy leached chernozem. The humus content is $4.5 \%$. On the data of analyses conducted in the university scientific research laboratory phosphorus (P2O5 by Chirikov) mobile forms level was 12.2-12.5 mg and of exchangeable potassium ( $\mathrm{K} 2 \mathrm{O}$ by Chirikov) $-6.5-7.3 \mathrm{mg}$ per $100 \mathrm{~g}$ of soil, $\mathrm{pH}(\mathrm{KCl})-5.5$. The variants repetition was 4 times. The plot area was $45 \mathrm{~m} 2(2.5 \times 18 \mathrm{~m})$. Fertilizer $\mathrm{N} 110 \mathrm{P} 60 \mathrm{~K} 60 \mathrm{~kg} / \mathrm{ha}$ a.d. was applied as background for the planned yield of $6 \mathrm{t} / \mathrm{ha}$, only nitrogen fertilizer was applied fractionally during the growing season. The seed rate was 400 pcs/ha. The winter wheat variety Nemchinovskaya 17 sowing was in the September 1st decade. Plots were harvested in sheaves in the full ripeness phase. Field experiments were conducted according to the B.A. Dospekhov method [8]. The winter wheat cultivation technology was generally accepted in the zone. Below are the preparations a brief description that was studied in the variety Nemchinovskaya 17 experiment and the commercial value.

Table 1. Scheme of experiments to study winter wheat seed dressing agents.

\begin{tabular}{|c|l|}
\hline $\begin{array}{c}\text { Variant } \\
\text { No. }\end{array}$ & \multicolumn{1}{|c|}{ Preparations, application rate } \\
\hline 1 & $\begin{array}{l}\text { Shansil Trio }(0.5 \mathrm{l} / \mathrm{t})+\text { Imidashans }(0.6 \mathrm{l} / \mathrm{t})- \\
\text { control }\end{array}$ \\
\hline 2 & $\begin{array}{l}\text { Sistiva }(0.75 \mathrm{l} / \mathrm{t})+\text { Kinto Duo }(2.0 \mathrm{l} / \mathrm{t})+ \\
\text { Imidashans }(0.6 \mathrm{l} / \mathrm{t})\end{array}$ \\
\hline 3 & Celest Max $(2.0 \mathrm{l} / \mathrm{t})$ \\
\hline 4 & Celest Top $(1.5 \mathrm{l} / \mathrm{t})$ \\
\hline 5 & $\begin{array}{l}\text { Shansometox }(1.5 \mathrm{l} / \mathrm{t})+\text { Shansil Ultra }(0.12 \mathrm{l} / \mathrm{t}) \\
+ \text { Energoshans }(0.21 / \mathrm{t})\end{array}$ \\
\hline 6 & Vybrance Integral $(2,0 \mathrm{l} / \mathrm{t})$ \\
\hline
\end{tabular}

Vybrance Integral, KS (175 g/ltr Thiamethoxam $+25 \mathrm{~g} / \mathrm{ltr}$ Sedaxan $+25 \mathrm{~g} / \mathrm{ltr}$ Fludioxonil $+10 \mathrm{~g} / \mathrm{ltr}$ Tebuconazole). This four-component product has insecticidal and fungicidal properties to protect winter wheat seeds from diseases and pests. This preparation application allows blocking diseases, namely, fusarium (Microdochium nivale), typhulosis (Typhula incarnata) and rhizoctonia (Rhizoctonia solani), as well as limiting the ground pest damage and soil pests. Active substances in the preparation belong to four chemical classes: neonicotinoids, carboxamides, phenylpyrroles, triazoles. Produced by Syngenta.

Celest Max, KS (125 g/l thiamethoxam + $25 \mathrm{~g} / 1$ fludioxonil + $15 \mathrm{~g} / \mathrm{l}$ tebuconazole). Chemical class: neonicotinoids, phenylpyrroles, triazoles. Celest Max is an insectofungicide that protects against complex pests (Chloropidae, Cecidomyiidae, Opomyzidae, Anthomyiidae, Agromizidae, Carabidae) and pathogens, but also favourably influences biological processes at crop organogenesis early stages. It controls the immunity of the plant by stimulating the production-specific anti-stressant proteins. As a result, plants better tolerate drought, soil salinization, sharp temperature fluctuations. All this contributes to the variety' genetic potential full realization. The preparation belongs to the hazard 2nd class, but by resistance in the soil - to the first. It is produced by Syngenta.

Celest Top, KS $(262.5 \mathrm{~g} / \mathrm{l}$ thiamethoxam $+25 \mathrm{~g} / \mathrm{l}$ diphenoconazole $+25 \mathrm{~g} / 1$ fludioxonil). In 2013, Syngenta introduced to the Russian market a new combined insectofungicide seed protectant, Celest Top, for the protection of winter grain crops with various etiologies controllable root rots an expanded spectrum. Celest Top is a high-tech solution for the winter wheat seedlings protection not only against pathogens but also against soil and ground pests many types. The product active ingredients belong to 3 chemical classes neonicotinoids, triazoles and phenylpyrroles. The winter wheat seed dressing use reduces the fungicidal and insecticidal agents tank mixtures use to protect vegetative plants. Produced by Syngenta. The presence in the preparations Vybrance Integral, Celest Max, Celest Top fludioxonil, designed to well suppress the pathogens' development from the genus Fusarium and Tilletia, causing cereal crops seedlings diseases [3]. 
Fludioxonyl does not have a toxic effect on the protected plant. Besides, its use does not cause cross-resistance [2].

Kinto Duo, KS ( $20 \mathrm{~g} / 1$ triticonazole $+60 \mathrm{~g} / 1$ prochlorase). It is a fungicide seed dressing for cereal crops, which is designed for seed disinfection and local soil disinfection: Microdochium nivale, Typhula incarnata, T. idahoensis, Claviceps purpurea. It is designed to solve problems in crop rotations with saturated grain crops in a high proportion. The prochloraz presence in the preparation, which has translocating action, successfully suppresses the infection on the surface and inside the seeds. The preparation belongs to two chemical classes: imidazoles and triazoles. The application norm on winter wheat is $2.5 \mathrm{~kg} / \mathrm{t}$. Producer BASF.

Sistiva, KS (333.3 g/l xemium (fluxapiroxad). This is a highly effective seed dressing, which provides long-term protection against leaf apparatus diseases and helps eliminate the need for fungicides early application in critical phases for crop organogenesis formation. BASF's new Sistiva fungicide has an AgCelence effect. Products with AgCelence effect are very good at helping plants survive various stressful situations: sudden temperature changes, cold, abnormal increase in air temperature, drought, etc. Plants stay healthier for longer by reducing the overall infection load, thus reducing the necessary foliar fungicide treatments number. The manufacturer recommends using products Sistiva (0.75-1.0 1/t) and Kinto Duo (2.0-2.5 1/t) as a tank mixture.

Shansil Trio, KS (thiabendazole $60 \mathrm{~g} /$ litre + tebuconazole $60 \mathrm{~g} /$ litre + imazalil $40 \mathrm{~g} /$ litre). The preparation contains three chemical classes' active substances: benzimidazoles, imidazoles and triazoles. This drug contains imazalil, which is characterized by high activity against Fusarium and Helminthosporium root rot pathogens, against pathogens resistant to benzimidazoles. The imazalil action is to inhibit sterol biosynthesis in fungal phytopathogens cell membranes, causing their membrane rupture [2].

Chansometox Trio, KS $(262.5 \mathrm{~g} / 1$ thiamethoxam $+25 \mathrm{~g} / 1$ diphenoconazole $+25 \mathrm{~g} / \mathrm{l}$ fludioxonil). Chemical class: triazoles, neonicotinoids and phenylpyrroles. Insectofungicide dressing is used as a protective pesticide, immunizing fungicide, treating fungicide for the diseases' treatment and prevention in winter wheat.

Shansil Ultra, KS (120 g/l Tebuconazole). Chemical class: triazoles. It is a single-component systemic fungicide designed for the prevention and treatment of, including winter wheat. Tebuconazole can increase the cereal crops diseases resistance in winter wheat to low temperatures through its effect on carbohydrate, protein, fatty acid and respiratory metabolism [9].

Imidashans, KS (600 g/l imidacloprid). Systemic insecticide for seed treatment. This drug application allows protecting the root system from damage by soil-dwelling insects in the period from seed germination to 35 days of young plants vegetation from aboveground pests. The preparation application is economically justified as it eliminates several insecticide sprays during the winter wheat initial vegetation period. The preparation enters the plant through the root system and protects crops from cereal flies, wireworms, fleas (cereals, crucifers), bread beetles, biting midges. It is dangerous for insects as it has an acute contactintestinal action and active effect on their nervous system, which leads to their death. Shansil Trio, SHansometoks Trio, SHansil Ul'tra, Imidashans are produced by Shans Enterprises Ltd.

Nemchinovskaya 17. This winter wheat variety in the Krupp farm takes the leading position. It is the erythrospermum variety a variety. It is one of the most valuable wheat varieties with good baking qualities and coarse, dyed grain. Under field conditions, the variety is affected by powdery mildew (Blumeria graminis) and brown rust (Puccinia recondita), suffers heavily from snow mold (Microdochium nivale) and is susceptible to hard smut (Tilletia caries). Therefore, the seed dressing studied by us, having multilateral fungicidal activity, to a sufficiently full extent should manifest its qualities against the above pathogens, which will subsequently affect the cenosis density. The variety has been included in the State Register since 2013 and is protected by the Russian Federation a patent.

\section{Results and Discussion}

Almost every agricultural year in our conditions is atypical. According to the Tula AGMS, agrometeorological conditions developed differently during the studies, which allowed the studied preparations to show their characteristics. Rainfall during the winter wheat growing season was uneven. At the September beginning, when the crop was sown, precipitation was insufficient to produce friendly and timely sprouting. Only $37.1 \%$ of the monthly norm fell, which subsequently affected the shoots completeness. The Selyaninov hydrothermal coefficient (HTC) for this period was 0.62, while the annual average was 1.71 . The wettest month was June, when precipitation was $82.3 \mathrm{~mm}$, exceeding the long-term average by $6.3 \mathrm{~mm}$, while May was the driest. Precipitation amounted to $11.2 \mathrm{~mm}$, which was 3.8 times less than the long-term average. The reproductive organs vegetative mass growth and formation period was characterized by insufficient productive moisture supply; however, there was good sunny weather, which subsequently affected the protein and gluten quantity and quality. Under our conditions with good sunny insolation, high-quality grain is formed. The temperature regime during the initial vegetation period exceeded the mean annual values by $2.6^{\circ} \mathrm{C}$ in May, by $2.0^{\circ} \mathrm{C}$ in June and by $1.0^{\circ} \mathrm{C}$ in August. In the rest months of vegetation corresponded to mean annual values. In general, climatic conditions during the study period were quite favourable for the food winter wheat cultivation and the preparations effectiveness evaluation.

Seeds field germination. The chemical dressers use for winter wheat seeds disinfestation has an impact on their germination. At a rate of seeding $400 \mathrm{pcs} / \mathrm{m}^{2}$ of germinating seeds in the field conditions, depending on the treatment agent, 201 to $309 \mathrm{pcs} / \mathrm{m}^{2}$ sprouted. Field germination was 50.2 to 
$77.3 \%$. The strongest reduction in seed germination was from the Celest Max (201 pcs $\left./ \mathrm{m}^{2}\right)$ application. The seeds maximum field germination was shown by Celest Top - $309 \mathrm{pcs} / \mathrm{m}^{2}$. This drug has a mild effect on winter wheat seeds, even when increasing the recommended dose by 2 times [12]. The same seed germination was in two variants - option 1 and option 5 $(62.2 \%)$. Almost the same field germination showed the preparation Vaibrans Integral.

Winter wheat yield structure. The productive stems (ears) number per unit area is the yield determining elements one. The phytocenosis optimal structure formation is influenced not only by the productive soil moisture availability but also by the pests and pathogens presence. In the research, the productive stems' number depended on the germinating plants' number per $1 \mathrm{~m} 2$ as well as on the winter wheat tillering intensity. The productive stems greatest number was in the variant where the seed dressing used Sistiva $(0.751 / t)+$ Kinto Duo $(2.01 / t)+$ Imidashans (0.6 1/t) - $477 \mathrm{pcs} / \mathrm{m} 2$ (tab. 2). Sistiva is intensively absorbed by the roots and evenly distributed in the leaf and stem tissues, thereby blocking the infection development and spread over a long time. As a consequence, winter wheat plants have a high guarantee to avoid becoming infected with diseases at the growing season beginning. The productive stems lowest number was in two variants - Chansometox (1.5 $1 / \mathrm{t})+$ Shansil Ultra $(0.12 \mathrm{l} / \mathrm{t})+$ Energoshans $(0.2 \mathrm{l} / \mathrm{t})$ and Vybrance Integral $(2.0 \mathrm{l} / \mathrm{t})$, respectively 438 and $439 \mathrm{pcs} / \mathrm{m}^{2}$.

The productive tillering coefficient ranged from 1.46 to 2.20. The most intensive tillering was with Celest Max as it promotes strong root development and with Sistiva in combination with Quinto Duo and Imidachans. The latter variant improved tillering efficiency through the combined preparations use with multilateral fungicidal and insecticidal activity. In the other variants, the tillering rate was less than 2.0 .

The amount of grains in the wheel depended on disinfectants. The best ear flattening was in the variants with Vybrance Integral $(2.0 \mathrm{l} / \mathrm{t})$, which subsequently affected the grains' weight per $1 \mathrm{~m} 2$, it was the highest $(701.2 \mathrm{~g})$, and ultimately the crop productivity as a whole.

The lowest ear number (29.5 pcs) was where the seeds were dressed with Celest Max (2.0 1/t). But even with the grains lowest number in the ear, this option received one of the grain yield highest rates per $\mathrm{m} 2-683.6 \mathrm{~g}$. This was influenced by the fact that winter wheat plants had the highest coefficient of tillering (2.2). In the other variants, the ear emergence rate was intermediate between the preparations Vybrance Integral and Celest Max.

A field yield level with winter wheat is largely determined by the grains' number formed per unit area. This indicator is called cenosis capacity [11]. Its main derivatives are productive stem density and the grains' number in the ear. The primary objective to increase the yield is to increase the productive bushiness, develop a strong root system, and obtain ears with grains a large number. All these traits have variation a wide range, varying considerably with the agronomic practices used to care for the crop. One such technique is the quality, modern seed dressing agents use to prepare the seeds for sowing. New modern protectants, having high disinfecting properties and physiologically active effect, protect seeds and seedlings, increase seed germination energy and germination, improve plant growth and development, increase grain yield.

The 1000 grains weight had fluctuations depending on the studied preparations. The grain on all variants was large and well fulfilled. The largest grains were in those variants where seeds were disinfected with preparations a complex combination: Shansometox $(1.5 \mathrm{l} / \mathrm{t})+$ Shansil Ultra $(0.12 \mathrm{l} / \mathrm{t})+$ Energoshans $(0.2 \mathrm{l} / \mathrm{t})$, the 1000 grains weight was $55.2 \mathrm{~g}$. The 1000 grains mass lowest values $(51.7 \mathrm{~g})$ were observed on the variant Sistiva $(0.751 / \mathrm{t})+$ Kinto Duo $(2.01 / \mathrm{t})+$ Imidashans $(0.6 \mathrm{l} / \mathrm{t})$. On the other studied variants, the grain with almost the same weight (53.0-53.3 g) was fielded.

Table 2. Winter wheat yield structure Main elements depending on seed dressing agents.

\begin{tabular}{|c|c|c|c|c|c|c|}
\hline $\begin{array}{l}\text { Trial } \\
\text { vari- } \\
\text { ant }\end{array}$ & $\begin{array}{l}\text { Plant } \\
\text { number } \\
\text {, pcs / } \\
\mathrm{m}^{2}\end{array}$ & $\begin{array}{l}\text { Produc } \\
\text { tive } \\
\text { ears } \\
\text { number } \\
\text { pcs } / \mathrm{m}^{2}\end{array}$ & $\begin{array}{l}\text { Bunchi- } \\
\text { ness } \\
\text { coeffi- } \\
\text { cient, } \\
\text { pcs. }\end{array}$ & $\begin{array}{l}\text { Grains } \\
\text { number } \\
\text { in ear, } \\
\text { pcs. }\end{array}$ & $\begin{array}{l}\text { Grain } \\
\text { weight } \\
\text { per } 1 \mathrm{~m}^{2} \text {, } \\
\mathrm{g}\end{array}$ & $\begin{array}{l}1000 \\
\text { grains } \\
\text { weight, } \\
\mathrm{g}\end{array}$ \\
\hline 1 & 249 & 457 & 1.84 & 33.0 & 653.5 & 53.2 \\
\hline 2 & 227 & 477 & 2.10 & 31.2 & 667.8 & 51.7 \\
\hline 3 & 201 & 442 & 2.20 & 29.5 & 683.6 & 53.0 \\
\hline 4 & 309 & 450 & 1.46 & 31.0 & 599.5 & 53.0 \\
\hline 5 & 249 & 438 & 1.76 & 29.7 & 635.2 & 55.2 \\
\hline 6 & 247 & 439 & 1.78 & 33.6 & 701.2 & 53.3 \\
\hline
\end{tabular}

The winter wheat yield depended on seed dressing and was high in the experiment. The maximum yield was obtained in variants, where as a seed dressing agent was used Vaibrans Integral at the rate of $2.01 / \mathrm{t}-7.23 \mathrm{t} / \mathrm{ha}$. The excess to the control variant (Shansil Trio + Imidashans) was $0.49 \mathrm{t} / \mathrm{ha}$ (7.3\%). This is because in addition to crop protection from pests Vaibrans Integral contributes to the fertilizer fertilizers effectiveness, which was carried out in the vegetation resumption phase and the flag leaf appearance phase. After all, the root system had a strong start and follow-up development. This preparation is designed to increase the crops' resistance to adverse growing conditions, especially the productive moisture lack in the soil. It happens because the preparation contains the active ingredient sedexan, which patented molecule is focused on a healthy and strong root system formation.

Somewhat less grain was obtained from using Celest Max $(2.0 \mathrm{l} / \mathrm{t})-7.05 \mathrm{t} / \mathrm{ha}$. The excess compared to the control variant was $4.6 \%$ (Table 3 ). This variant had the bushiness highest coefficient, which had a positive effect on productivity.

The grain least amount was obtained on the 4th option (Celest Top (1.5 1/t) - $6.17 \mathrm{t} / \mathrm{ha}$. This option had the lowest coefficient of tillering (1.46) at the same time as the plants maximum density. When using Celest Top for winter wheat seed disinfestation, avoid increasing the seeding rate. 
Table 3. Winter wheat grain yield and quality depending on protectants.

\begin{tabular}{|c|c|c|c|c|}
\hline \multirow{2}{*}{$\begin{array}{l}\text { Trial } \\
\text { variant }\end{array}$} & \multirow{2}{*}{$\begin{array}{l}\text { Yield at } \\
\text { standard } \\
\text { humidity, } \\
\text { t/ha }\end{array}$} & \multicolumn{2}{|c|}{ Grain content, \% } & \multirow{2}{*}{$\begin{array}{l}\text { IDC device } \\
\text { readings, } \\
\text { gluten quality }\end{array}$} \\
\hline & & protein & gluten & \\
\hline 1 & 6.74 & 15.53 & 36.8 & 70 (good) \\
\hline 2 & 6.88 & 15.79 & 29.2 & 57 (good) \\
\hline 3 & 7.05 & 15.18 & 35.6 & $67($ good $)$ \\
\hline 4 & 6.17 & 15.77 & 34.4 & $50($ good $)$ \\
\hline 5 & 6.54 & 15.43 & 37.6 & 66(good) \\
\hline 6 & 7.23 & 16.07 & 36.8 & 57 (good) \\
\hline NSR 05 & 0.14 & 0.06 & 0.17 & - \\
\hline NSR \% & 2.07 & 0.4 & 0.5 & - \\
\hline
\end{tabular}

Seed dressing agents had an impact not only on the production quantity but also on the grain quality. The wheat grain most important technological property is its protein and gluten content since these parameters both determine the wheat use nature. In Russia, baking requires wheat with a protein content of $14-15 \%$, for pasta production from 17 to $18 \%$. Anything below the above values is fodder grain, which is used to feed livestock or for technical purposes and such products price is much lower. Therefore, the producer tries to grow food grain with protein and gluten high indicators.

Only food grain with high protein and gluten content was obtained in all study variants. Moreover, gluten by the IDK instrument indices was the I group only and it's quality according to GOST 13586.1-68 is good. Good gluten is very important for the baking industry because it has high tensile strength and does not break. The indices relating to baking technology - volume yield, height to diameter ratio, the bread porosity and appearance - are the higher the more protein and gluten there is in the wheat grain. In the variants, a crosssection, the grain with the highest gluten content-37.6\%-was obtained on variant 5 . This is because during dressing used bio stimulator Energoshans, which contains $60 \mathrm{~g} / 1$ nitrogen, $25 \mathrm{~g} / 1$ phosphorus, $60 \mathrm{~g} / \mathrm{l}$ potassium, seaweed extract with microelements $200 \mathrm{~g} / \mathrm{l}$, alginic acid $10 \mathrm{~g} / \mathrm{l}$ and $50 \mathrm{~g} / \mathrm{l}$ organic matter. These substances combination contributed to a significant increase in these substances quality. Pre-sowing seed disinfection with Sistiva dresser together with Quinto Duo and Imidashans showed that the gluten content was the lowest in this variant $(29.2 \%)$. On the other variants, the raw gluten content ranged from $34.4 \%$ (variant 4) to $36.8 \%$ (variants 6 and 1).

Nowadays, when selling grain for export, the protein content is taken into account, not the gluten content. While gluten quantitative indicators in wheat grain are closely related to protein content $(\mathrm{r}=0.90-0.98)$, gluten properties are the variety solely a characteristic and are not related to the total protein content in the grain. The maximum protein content was on the variants with Vaibrans Integral - 16.07\%. On the other variants, this indicator had a variation from 15.18 to $15.79 \%$, which is also good. Grain protein content, although highly variable, is a genetically determined varietal trait. But if the same variety grown under the same conditions accumulates protein in different amounts, this was influenced by the preparations we studied.

\section{Conclusion}

Currently, for winter wheat seed dressing it is best to use insectofungicide preparations, which should contain different chemical classes several components. The best indicators for productivity $(7.23 \mathrm{t} / \mathrm{ha})$ and grain quality were obtained by using a four-component insectofungicide for winter wheat seed dressing Vaibrans Integral, KS at the $21 / t$ rate. This preparation application provides an especially high protein content in grain $(16.07 \%)$ and gluten $(36.8 \%)$ of the I quality group. Celest Top application, KS (1.5 1/t) did not increase the winter wheat productivity compared with other options. This option received the lowest yield $(6.17 \mathrm{t} / \mathrm{ha})$, but the grain was of high quality. All studied preparations are suitable for winter wheat seeds disinfecting from seed and soil pathology and pests of early plant development and are of technological and economic necessity for crop cultivation. In subsequent phases of winter wheat growth and development, fungicidal and insecticidal treatments are required to protect the leaf apparatus and spike: in the colosation phase (BBCH 51-59), flowering (BBCH 65-69) and grain filling (BBCH 71-83), but already with other drugs.

\section{References}

[1] Abelentsev V.I. Modern seed dressing agents' possibilities for grain crops/V.I. Abelentsev//Plant protection and quarantine. - 2011. - No. 2. - pp. 19-21.

[2] Beletskaya M.N. The modern grain dressing agents active substances research and comparative analysis / M.N. Belitskaya, I.R. Gribust, E.V. Baybakova, E.E. Nefedieva, I.G. Shaikhiev//The Technological University Bulletin. 2015. - T.18. - No. 9. - pp. 32-36.

[3] Berezhnaya E.V. The fungicide azoxystorobin growthinhibiting effect peculiarities and its ability to inhibit the sugars consumption in the winter wheat sprout. Berezhnaya, A.V. Korsukova, O.A. Fedotova [et al.]//Izvestiya vuzov. Applied Chemistry and Biotechnology. - 2020. - T. 10. - No. 4. - pp. 657-665.

[4] Govorov D.N. Phytoexamination and pre-sowing seed treatment are the grain cultivation technology most important methods/D.N. Govorov, A.V. Zhivykh, P.B. Schetinin//Plant protection and quarantine. - 2018. - No. 8. - pp. 12-13.

[5] The pesticides and agrochemicals State catalogue approved for use in the Russian Federation territory. Part I. Pesticides. Part II. Agrochemicals (official publication). Information as of February 8, 2021. - Moscow, 2021 [Electronic resource]. - Access mode: http://www.mcx.ru (date of access: 15.03.2021). 
[6] Gulidova V.A. Crops infected seeds and their protection: monograph/V.A. Gulidova. - Yelets: FSBEI HE The Yelets State University named after I.A. Bunin, 2010. $281 p$.

[7] Gulidova V.A. The winter wheat crops phytosanitary state optimization: monograph/V.A. Gulidova. - Yelets: FSBEI HE The Yelets State University named after I.A. Bunin, 2020. - 277p.

[8] Dospekhov B.A. Field experiment methodology (with the research results from statistical processing basics): a textbook for higher agricultural educational institutions students in agronomic specialities/Dospekhov B.A. - 6th ed., Erased, reprinted from the 5th ed. 1985. - M.: Alliance, 2011.-- 351p.

[9] Korsukova A.V. Increase in spring wheat seedlings cold resistance during seed treatment with tebuconazole / A.V. Korsukova, O.A. Borovik, O. I. Grabel [and others]//Universities News. Applied Chemistry and Biotechnology. - 2015. - No. 4. - pp. 30-36.

[10] Lipchinskaya R.A. Phytoexamination is the seed control most important element/R.A. Lipchinskaya//Plant protection and quarantine. - 2021. - No. 2. - pp. 3-4.

[11] About carrying out a spring fieldwork complex using the Centre scientific achievements and recommendations in 2020: recommendations of the FSBSI "Scientific Center for Plant named after P.P. Lukyanenko "/A.A. Romanenko, L.A. Bespalova, I.N. Kudryashov [and others]. - Krasnodar: EDVI, 2020.-- 136 p.

[12] Pavlyuk N.T. Disinfectants influence on the grain seeds sowing quality/N.T. Pavlyuk, G.D. Shentsev. - The VoronezhGAU Bulletin. - 2016. -No. 4 (51). - pp. 21-25.

[13] Fedotov V.A. Winter soft wheat in the Central Black Earth Region of Russia: monograph/V.A. Fedotov. - Voronezh: FSBEI HE "The Voronezh GAU", 2016. - 415 p.

[14] Schroeder KL, Paulitz TC Root Diseases of Wheat and Barley During the Transition from Conventional Tillage to Direct Seeding//Plant Disease, 2006, v. 90, pp. 12471253.

[15] Shchuchka, RV, Gulidova, VA Methods and results of spring barley plants treatment with growth biostimulants (2021) IOP Conference Series: Earth and Environmental Science, 677 (2), \# 022103, DOI: 10.1088/1755$1315 / 677 / 2 / 022103$

https://www.agro.basf.ru

https://www.syngenta.ru

https://www.shans-group.com.ru

About the Authors

Gulidova Valentina Andreevna. Doctor of Agricultural Sciences: 06.01.01, 06. 01.09, Professor, the Russian Federation agriculture honoured worker, the agricultural products storage and processing department technology Professor. FSBEI HE the Yelets State University named after I.A. Bunin, ORCID 0000-0001-7585-0956, Author ID 57131091400

Tel. 8-920-244-47-15. Email: Guli49@yandex.ru .
Shchuchka Roman Viktorovich. Candidate of Agricultural Sciences, the Agrochemistry and Soil Science Department Associate Professor. The Yelets State University named after I.A. Bunin ORCID 0000-0002-1011-5413, Author ID 57208116311

Tel. 8 (47467) 6-59-71 E-mail: Romanelez@yandex.ru

\section{Valentina A. Gulidova}

Doctor of Agricultural Sciences, Professor, the agricultural products storage and processing technology Dept. head. Chair, the Bunin Yelets State University, Russian Federation, ORCID 0000-0001-7585-0956, Author ID 57131091400

Tel. 8 (47467)6-59-71 E-mail: Guli49@yandex.ru .

\section{Roman V. Shchuchka}

Candidate of Agricultural Sciences, the Agrochemistry and Soil Science Department Associate Professor. The Bunin Yelets State University, the Russian Federation, ORCID 00000002-1011-5413, Author ID 57208116311

Tel. 8 (47467) 6-59-71 E-mail: Romanelez@yandex.ru

\section{Creative Commons Attribution License 4.0 (Attribution 4.0 International , CC BY 4.0)}

This article is published under the terms of the Creative Commons Attribution License 4.0

https://creativecommons.org/licenses/by/4.0/deed.en_US 